\title{
An Assessment Tool for Babies Requiring Continuous Positive Airway Pressure or High Flow
}

\section{Susan Lamburne*}

NICU, Southmead Hospital, Bristol, UK

"Corresponding author: Susan Lamburne, NICU, Southmead Hospital, Bristol, UK, E-mail: susan.lamburne@nbt.nhs.uk

Received date: January 28, 2016; Accepted date: February 19, 2016; Published date: March 14, 2016

Copyright: ( 2016 Lamburne S. This is an open-access article distributed under the terms of the Creative Commons Attribution License, which permits unrestricted use, distribution, and reproduction in any medium, provided the original author and source are credited.

\section{Assessment Tool for Babies}

A trend towards an increased use of nasal continuous positive airway pressure (nCPAP) has arisen from several studies that have provided evidence of decreased lung damage and reduced incidence of chronic lung disease in neonates [1,2]. Nasal CPAP is an effective treatment modality for neonates with bronchopulmonary dysplasia (BPD) and respiratory disease [3]. External or internal complications of nCPAP and High Flow can be relatively frequent and close surveillance for potential complications must be considered during nCPAP and High flow use.

One study reports an overall internal or external complication rate of $13.2 \%$, including tissue necrosis, intranasal ulceration, granulation, and vestibular stenosis [4]. Care givers providing close observations, i.e. hourly assessment of the infant's nares have the unique opportunity to identify and assess these possible complications.

It is therefore of vital importance that bedside care givers understand the nCPAP and high flow system they are using to prevent tissue break down. Nurses caring for infants receiving nasal CPAP or Nasal high flow work through a CPAP competency and a high flow competency. The Practice Development and Respiratory teams at the
Neonatal Intensive Care Unit at Southmead Hospital, Bristol, UK devised a set of guidelines that include a CPAP competency and a CPAP care plan and a High Flow competency. In accordance with the Department of Health's Toolkit for High Quality Neonatal Services, staff to undergo training to achieve these competencies [5].

To try to prevent nasal scarring and excoriation the nCPAP and High Flow assessment tool was introduced with the neonatal Intensive care Unit at Southmead Hospital, Bristol, UK in 2008. This chart has since been updated, please see attached chart table 1. Staffs are encouraged to use the score chart effectively together with the specific nCPAP care plan and nasal high flow and nCPAP competencies. The score chart is integrated within the NICU's care chart and on an hourly basis the infant's nares are assessed and scored and any evidence of skin break down is identified and quickly managed appropriately.

Since the introduction of the nasal assessment tool there has been a marked reduction in the number of nasal injuries and the extent of damage. The assessment tool is a simple staging system that, when used together with the nCPAP competency, nasal High Flow competency and nCPAP care plans serves as a strategy for prevention and treatment to this iatrogenic and cutaneous event.

\begin{tabular}{|c|c|c|}
\hline Signs & Score & Action \\
\hline Nares appear healthy & 0 & No action required \\
\hline $\begin{array}{c}\text { Slight redness noted around } \\
\text { nares, Area appears painful to } \\
\text { touch, Some indentation noted }\end{array}$ & 1 & $\begin{array}{r}\text { Ensure the baby is wearing the correct size hat/mask/prong as per NICU guidelines and that all are correctly } \\
\text { positioned, Assess/discuss with Senior nurse/Registrar/Consultant if a change in mask/prongs is needed or consider } \\
\text { a change of device (ex: Bubble-Drager-NCPAP), Document on ITU chart and in notes }\end{array}$ \\
\hline $\begin{array}{c}\text { Any of the following evident: } \\
\text { Marked indentation, Painful to } \\
\text { touch, Tissue breakdown }\end{array}$ & 2 & $\begin{array}{r}\text { Call Senior nurse/Registrar/Consultant, Remove mask /prongs immediately ensuring baby's breathing remains } \\
\text { supported (Neopuff PEEP), Decide on appropriate alternative respiratory support, Document on ITU chart, in notes } \\
\text { and complete eAIMS, Dr to refer to plastics and obtain medical imaging }\end{array}$ \\
\hline @ S F Lamburne August 2008, Updated by CJ 2014, North Bristol NHS Trust UK \\
\hline
\end{tabular}

Table 1: An assessment tool for a baby receiving CPAP via Drager/NCPAP or bubble.

\section{Acknowledgements}

The author would like to acknowledge the following health care workers; Sue Prosser, Dr David Evans, Michelle Jackson, Anna Colwill Kirsty Wright Claire Johnson.

\section{References}

1. Aly H, Milner JD, Patel K, El Mohandes AE (2004) Does the experience with the use of nasal continuous positive airway pressure improve over time in extremely low birth weight infants? Pedriatrics 114: 697-702.

2. Kumar P, Kiran PS (2004) Changing trends in the management of respiratory distress syndrome (RDS) Indian J Pediatr 71:49-54.
3. Subramanian P, Henderson-Smart DJ, Davis PG (2005) Prophylactic nasal continuous positive airways pressure for preventing morbidity and mortality in very preterm infants.Cochrane Database Syst Rec 3: CD001243.

4. Jatana KR, Oplatetek A, Stein M, Phillips G, Kang DR, et al. (2010) Effects of nasal continuous positive pressure and cannula use in the neonatal intensive care setting .Arch Otolaryngology Head Neck Surg 136: 287-291.

5. Department of Health (2009) Toolkit for High Quality Neonatal Services. Available from:www.dh.gov.uk. 